Esta publicación cientifica en formato digital es continuidad de la revista impresa ISSN-Versión Impresa 0798-1406 / ISSN-Versión on line 2542-3185Depósito legal pp
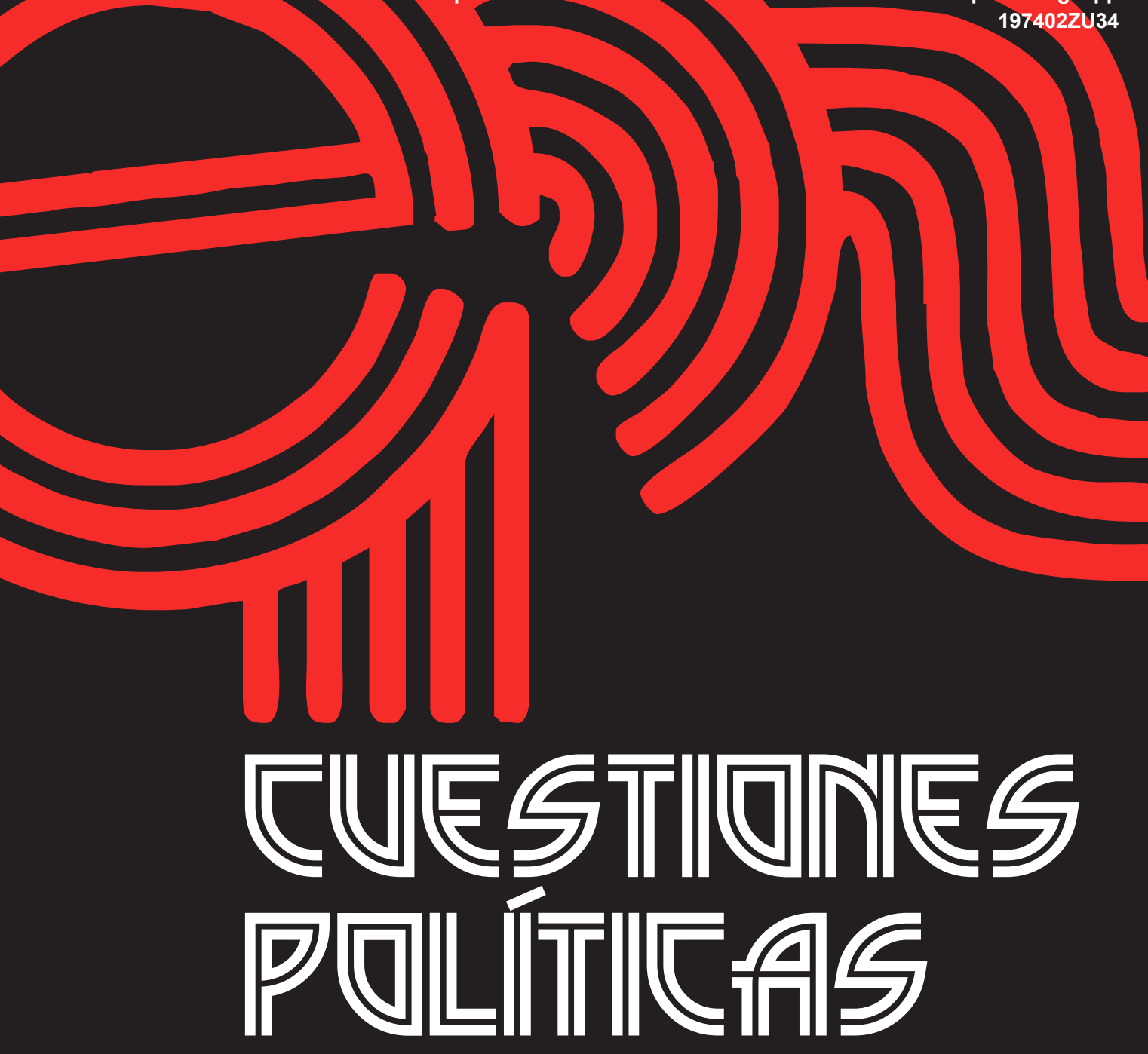

Instituto de Estudios Políticos y Derecho Público "Dr. Humberto J. La Roche" de la Facultad de Ciencias Jurídicas y Políticas de la Universidad del Zulia Maracaibo, Venezuela
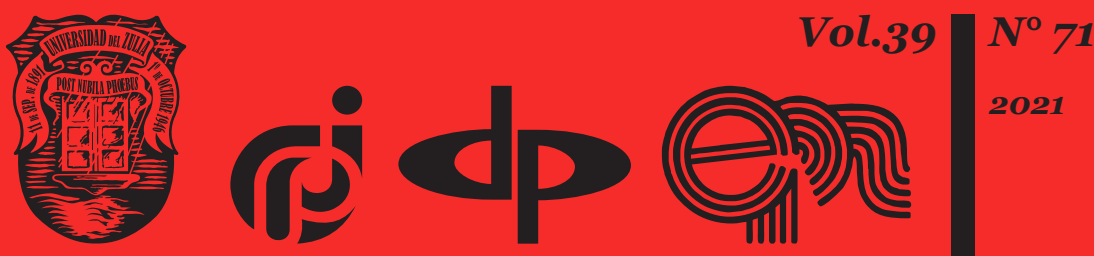


\title{
Experience in the legal regulation of international cooperation in police activity
}

\author{
DOI: https://doi.org/10.46398/cuestpol.3971.15
}

\author{
Oleksandr Mykhailyk * \\ Vitalii Yurakh ** \\ Denys Denysiuk *** \\ Anastasia Korniichenko **** \\ Nadiya Shevchenko ${ }^{* * * * *}$
}

\begin{abstract}
The objective of the research was to reveal the experience in the legal regulation of international collaboration in the police and further define opportunities to use this experience in Ukraine. The need to study the successful experience of administrative and legal regulation of international police cooperation, is emphasized in order to determine the possibility of using this experience proactively, and developing ways to improve the quality of administrative and legal regulation of international police cooperation in Ukraine. Materials and methods based on the analysis of documentary sources were used. It is concluded that the main advantages of administrative and legal regulation of international police cooperation in the investigated countries, should be taken into account to improve the mechanism of administrative and legal regulation of international cooperation in the National Police of Ukraine, with respect to implementing better and more effective provisions of its activities, which includes: introduction of special international training programs, retraining, advanced training (internship) of police personnel for the creation of an institute for international
\end{abstract} cooperation in various spheres of its activity.

* Doctor of Law, Professor of the Department of History and Theory of State and Law Higher Educational Institution "Interregional Academy of Personnel Management". ORCID ID: https://orcid.org/oooo0002-0644-1494

** Doctor of Jurisprudence, associate professor, associate professor of department of right and lawenforcement activity of the Central Ukrainian State Pedagogical University. ORCID ID: https://orcid. org/oooo-0003-1705-389X

*** Candidate of Law, Associate Professor, Deputy Chairman of the Bucha District State Administration of Kyiv Region, street Institutskaya, 22, Bucha, Kyiv. ORCID ID: https://orcid.org/oooo-0002-98879783

**** Doctor of Philosophy (081 Law), Senior Lecturer of Department of Law and Law Enforcement of Volodymyr Vynnychenko Central Ukrainian State Pedagogical University. ORCID ID: https://orcid. org/oooo-0002-7826-4386

***** Nadiya Shevchenko, Candidate of Law, Associate Professor of Administrative Law and Administrative Procedure, Kherson Faculty, Odessa State University of Internal Affairs. ORCID ID: https://orcid. org/oooo-0oo1-8131-5757 
Keywords: international police experience; International cooperation; prospects for implementation; comparative research; police science.

\section{Experiencia en la regulación jurídica de la cooperación internacional en la actividad policial}

\section{Resumen}

El objetivo de la investigación fue revelar la experiencia en la regulación legal de la colaboración internacional en la policía y además definir oportunidades para usar esta experiencia en Ucrania. Se enfatiza en la necesidad de estudiar la experiencia exitosa de la regulación administrativa y legal de la cooperación policial internacional a fin de determinar la posibilidad de utilizar esta experiencia proactivamente y desarrollar formas de mejorar la calidad de la regulación administrativa y legal de la cooperación policial internacional en Ucrania. Se utilizaron materiales y métodos basados en el análisis de fuentes documentales. Se concluye que las principales ventajas de la regulación administrativa y legal de la cooperación policial internacional en los países investigados, debe tenerse en cuenta para mejorar el mecanismo de regulación administrativa y legal de la cooperación internacional en la Policía Nacional de Ucrania con respecto a implementar mejores y más efectivos provisiones de sus actividades, lo que incluye: introducción de programas internacionales especiales de formación, reciclaje, formación avanzada (pasantía) de personal policial para la creación de un instituto de cooperación internacional en diversas esferas de su actividad.

Palabras clave: experiencia internacional policial; cooperación internacional; perspectivas de implementación; investigación comparada; ciencias policiales.

\section{Introduction}

In recent years, Ukraine has kept its course for European integration, which requires it to bring domestic legislation in line with the EU legislation, in particular this concerns legal regulation of international cooperation between the bodies and subdivisions of the National Police. This state of affairs presupposes necessity of studying foreign experience (including European experience) in the legal regulation of international cooperation in activities of police and international law enforcement organizations. 
Oleksandr Mykhailyk, Vitalii Yurakh, Denys Denysiuk, Anastasia Kormïchenko y Nadiya Shevchenko Experience in the legal regulation of international cooperation in police activity

Analyzing the process of formation of legal bases of cooperation in police activity in the leading countries of the world, their essential transformations and changes will give an opportunity to allocate directions which are important for definition of conceptual bases for improvement of administrative and legal regulation of international cooperation of bodies and divisions of the National police of Ukraine.

The European integration course of Ukraine, bringing domestic police legislation in line with the legislation of the EU countries and establishing international cooperation between the bodies and subdivisions of the National Police of Ukraine determine the necessity to study foreign experience of administrative and legal regulation of international cooperation in police activities as well as the necessity to borrow ways of its introduction into the national system of law and legislation.

\section{Literature review}

I.V. Skorohod notes that the present day situation requires further elaboration of development directions and more detailed analysis of their prospects. On the one hand, not all experiences are successful and on the other hand, as the author points out - not all experiences can be implemented at once Research of international experience in legal regulation of international cooperation of police activity in various spheres always causes scientific interest, which is also connected with rather variable legislation in the mentioned sphere (Kulish, 2020).

According to A.M. Chorna a number of reform processes is taking place in Ukraine today, in particular, due to the fact that our country seeks to integrate into the highly developed Western European community. This explains the need to introduce rules and standards that are commonly adopted in a civilized democratic world into all spheres of our public life. In this regard, the study of foreign countries' experience in formulation and implementation of state policy in key areas of public life is of particular importance (Chorna, 2018).

Successful foreign experience of the Armed Forces of Latvia, Lithuania and Estonia shows that the effectiveness of the functioning and operation of Armed Forces depends on a clear definition of key priorities in the sphere of defense, chains of international cooperation and proper logistics. In order to intensify international cooperation and implement NATO standards, Ukraine has already taken a large number of steps toward closer integration into the North Atlantic Alliance, but implementation of NATO standards defined at the regulatory and legal level does not yet mean their actual implementation, which requires a number of resources, including adequate level of material and technical support (Chumak, 2019). 
Studying certain directions of activity of the police of Ukraine, in particular counteraction to different forms of cybercrime taking into account international experience, V.V. Chumak points out that international activities of the cyberpolice of Ukraine acquires a special importance in connection with the rapid development of information technologies that destabilizes normal functioning of the cyber society , and violates rights and fundamental freedoms of persons and citizens (Ilchenko, 2019). A reliable guarantee of proper functioning of the European space of justice, freedom and security consists in provision of the necessary level of law and order not only on the territory of each member state of the European Union and the entire international community as a whole, but also on the territories adjacent to it.

Thus, as indicated by O.I. Bezpalova a characteristic feature of the common space of justice, freedom and security is presented as the need to ensure a harmonious combination of its two aspects: external and internal. It is clear that the internal aspect of this space presupposes consolidation of efforts of law enforcement bodies of the European Union member states aimed at insurance of internal security and maintenance of law order throughout the Community, creation of a number of specialized bodies (institutions) whose activity should be directed at the promotion of the work of national law enforcement bodies (Chumak, 2019).

Thus, taking into account that at present the Institute of International Cooperation of bodies and subdivisions of the National Police of Ukraine is at the stage of its formation, the urgent need is to study successful foreign experience of legal regulation of international cooperation in police activity in order to determine the possibility to use this experience in Ukraine and to develop ways of qualitative improvement of administrative and legal regulation of international cooperation of the police in Ukraine.

\section{Materials and methods}

Research of materials and methods based on the analysis of documentary sources and normative legal acts of foreign countries. The dialectical method of knowing the facts of social reality is the basis on which formallegal and rather legal approaches are largely based. The formal-dogmatic method contributed to the development of the author's explanation of the current state, problems, problems and practical role of legal technologies for the further development and improvement of police activities in foreign countries (Myronets et al., 2021). The official legal method allowed to suggest directions and types of use of legal technologies as prospects of police activity in foreign countries. 
Oleksandr Mykhailyk, Vitalii Yurakh, Denys Denysiuk, Anastasia Kormïchenko y Nadiya Shevchenko Experience in the legal regulation of international cooperation in police activity

\section{Results and discussion}

Introduction of European standards and values in the social, legal and economic spheres of the Ukrainian way of life, as well as introduction of the world best practices in domestic legal thought entails not only changes in existing regulations and dogmas, but also emergence of new norms and rules which are sometimes contrary to the current legislation. A special role in almost all European integration processes is played by changes brought to the current legislation of Ukraine which Ukraine has undertaken to implement in real life (Smirnova, 2010).

We would like to start the research with analysis of the administrative and legal regulation of international police cooperation in France, where protection of national interests has been determined as a priority direction of activity of all public authorities (National Police of France, 2021).

The National Police of France (French: Police nationale) is one of the two national police organizations of the country, along with the National Gendarmerie of France. The National Police of France was created

on August 14, 1941 by the Vichy Government to replace the General Directorate of National Security and came under the leadership of the Fourth French Republic in 1946. The National Police is part of the French Ministry of the Interior (hereinafter - the FMI). The National Police works mainly in urban areas, and in rural areas law enforcement functions are performed mainly by the Gendarmerie (National Police of France, 2021).

Since international police cooperation in France is at a fairly high regulatory level the National Police has an international technical cooperation service which takes care of international police cooperation and defines criminal law, criminal procedure, criminology, organizational law and international spheres of activity of the National Police of France.

It should be emphasized that the International Technical Cooperation Service of the National Police closely cooperates with the Office of International Cooperation of the FMI, which serves as a guarantee of an effective legal mechanism for implementation of international cooperation of the Police of France.

Interaction between the mentioned subdivisions takes place on the following principles:

- ensuring participation of each police officer in international cooperation in the relevant sphere of his activity.

- control by the International Cooperation Department of the FMI over compliance with legislation in the sphere of international police cooperation, assessment, and analysis for compliance with modern challenges. 
- establishing effective cooperation between the National Police of France and foreign police authorities and international law enforcement organizations.

- taking into account opinion of the International Technical Cooperation Service of the National Police during the formation of agreements on cooperation of the National Police by the International Cooperation Department of the FMI (Leheza et al., 2021).

The mentioned body plays a coordinating role in the mechanism of international cooperation of the National Police of France in order to promptly resolve issues within its competence.

And finally, we should note that international cooperation between the bodies and units of the National Police of Ukraine and the National Gendarmerie (Police) of France is an important component in the integral mechanism for detecting and combating international threats (terrorism, smuggling, human trafficking) (Leheza et al., 2018).

Thus, the experience of legal regulation of international cooperation in the activities of the National Police of France shows an effective system of bodies engaged in international cooperation. Specially established bodies for international cooperation are the key link through which police officers are able to more effectively perform their tasks and functions assigned to them by law.

In our opinion, the experience of administrative and legal regulation of international cooperation of such an International law enforcement structure as the International Association of Gendarmerie and Police Forces with Military Status (FIEP) is interesting. FIEP was established to develop law enforcement and military cooperation and exchange of experience between related entities. FIEP is an Association of Gendarmeries and Police Forces with Military Status The purpose of FIEP (which was started from the Armed Forces of France, Italy, Spain and Portugal) is to expand and strengthen mutual relations, promote innovative and active analysis of forms of police cooperation and appreciate its model of organization and structures abroad (Leheza et al., 2020).

Therefore, it is clear that this organization is called upon to establish international cooperation not only between the police authorities of the Association, but also with other related bodies, such as the gendarmerie and the National Guard. We should also point out activities of NordicBaltic Network of Policewomen (NBNP), which was founded in April 2001 in Riga. Its members are presented by all the countries of the Northern Europe - Sweden, Finland, Iceland and Denmark, as well as by the Baltic States - Lithuania, Latvia and Estonia, which, as a member of the network, actively participates in organized events. 
Oleksandr Mykhailyk, Vitalii Yurakh, Denys Denysiuk, Anastasia Kormïchenko y Nadiya Shevchenko 314 Experience in the legal regulation of international cooperation in police activity

The main task of the NBNP is to promote equal opportunities for women and men in police, increase the number of women in leadership positions in police, and to establish good professional relations and exchanges between police organizations in the Member States (Leheza et al., 2021).

This network strengthens professional relations and contacts between member states and seeks to ensure equal conditions for national police forces. Exchange of information and knowledge, creation of various exchange programs for policewomen, as well as organization of conferences and seminars are the main means for achieving the goals.

Thus, at present, the main tasks of the programs on which law enforcement bodies of Ukraine cooperate with European structures are to strengthen Ukraine's capacity concerning ensuring implementation of European international agreements in the sphere of crime prevention and support of international security. Of course, many initiatives have been implemented, but due to the challenge of the modern times many problems in the legal sphere require further joint attention (Halaburda et al., 2021).

\section{Conclusions}

Thus, the main advantages of administrative and legal regulation of international police cooperation in the researched countries, which, in our opinion, must be taken into account when improving the mechanism of legal regulation of international cooperation in the National Police of Ukraine for better and more efficient ensuring their activities, are as follows:

- introduction of special international programs on training, retraining, advanced training (internship) of police personnel on issues of establishing the institute of international cooperation in various spheres of their activity.

- establishing close international partnerships in the sphere of forensic support between research forensic centers of the Ministry of Internal Affairs of Ukraine.

- creation of an extensive network of counseling centers at institutions with specific training conditions of the Ministry of Internal Affairs of Ukraine in order to supplement the educational process with mechanisms of international interaction of cadets and master's degree students and representatives of foreign police organizations (law enforcement), institutions and services.

- ensuring deep and systematic interaction of the International Cooperation Department of the Ministry of Internal Affairs of Ukraine with other international police departments and services. 
- $\quad$ strengthening the role of the International Cooperation Department of the National Police of Ukraine as a coordination center for interaction of bodies and units of the National Police of Ukraine with other international law enforcement organizations, foreign police bodies and services.

- active introduction of electronic interaction between cybercrime counteraction units.

- establishment of international mechanisms for conducting operational and search activities.

- introduction of an ethics code for police officers on ethical standards of international police cooperation.

\section{Bibliographic References}

CHORNA, Alina. 2018. Administrative and legal mechanism for ensuring the rights of business entities in the field of taxation: dis. ... Dr. Jurid. Science. Kharkiv, Ukraine.

CHUMAK, Volodymyr. 2019. "Activities of the Armed Forces of Latvia, Lithuania and Estonia: experience for Ukraine" In: Bulletin of Kharkiv National University of Internal Affairs. Vol. 87, No. 4, pp. 162-169.

CHUMAK, Volodymyr. 2019. Organizational and legal bases of activity of KNAB of Latvia and DBR of Ukraine: the comparative analysis. The role and place of law enforcement agencies in building a democratic state governed by the rule of law: materials of the XI International. scientificpractical inter-conf, pp. 60-61. Kiev, Ukraine.

HALABURDA, Nadiia; LEHEZA, Yevhen; CHALAVAN, Viktor; YEFIMOV, Volodymyr; YEFIMOVA, Inna. 2021. "Compliance with the principle of the rule of law in guarantees of ensuring the legality of providing public services in Ukraine" In: Journal of law and political sciences. Vol. 29, No. 4, pp. 100-121.

ILCHENKO, Alexander. 2019. "Fishing as a cybercrime in the internet banking system: economic and legal aspects" In: Business Laws and Legal Rights: Research and Practice. Vol. 2, No. 7, pp. 115-129.

KULISH, Anatoly. 2020. "Measures to combat smuggling and corruption in the customs clearance of commercial goods in Ukraine" In: Amazonia Investiga. Vol. 9, pp. 99-110. 
LEHEZA, Yevhen; ODYNTSOVA, Iryna; DMYTRENKO, Natalia. 2021. "Teoría y regulación legal del apoyo informativo de los procedimientos administrativos en Ucrania" In: Ratio Juris UNAULA. Vol. 16, No. 32, pp. 291-306.

LEHEZA, Yevhen; SAVIELIEVA, Maryna; DZHAFAROVA, Olena. 2018. "Structural and legal analysis of scientific activity regulation in developed countries" In: Baltic journal of economic studies. Vol. 4, No. 3, pp. 147157.

LEHEZA, Yevhen; TIUTCHENKO, Svitlana; STANINA, Olha; SHATRAVA, Serhii; REZANOV, Serhii. 2021. "Uso y protección del suelo: regulación legal y experiencia extranjera" In: Revista de la Universidad del Zulia. Vol. 12, No. 33, pp. 70-81.

MYRONETS, Oksana; OLEFIR, Viktor; GOLOSNICHENKO, Ivan; PYVOVAR, Yuriy. 2021. "Tecnologías legales como instrumentos para la mejora de la seguridad de la aviación civil en las condiciones de la lucha contra COVID-2019. In: Revista de la Universidad del Zulia. Vol. 12, No. 32, pp. 444-459.

NATIONAL POLICE OF FRANCE. 2021. Wikipedia: vol. encyclical. Available online. In: https://en.wikipedia.org/wiki/\%Do\%9D\%Do\%Bo\%D1\%86 \%D1\%96\%Do\%BE\%Do\%BD\%Do\%Bo\%Do\%BB\%D1\%8C \% Do\% BD\% Do\% Bo_\% Do\% BF\% Do\% BE\% Do\% BB\% D1\% 96\% D1\% 86\% D1\% 96\% D1\% 8F_\% Do\% A4\% D1\% 80\% Do\% Bo\% Do \% BD\% D1\% 86\% D1\% 96\% D1\% 97. Consultation date: 19/04/2021.

SMIRNOVA, Alexandra. 2010. "French experience in countering terrorism" In: Bulletin of Nizhny Novgorod University. N.I. Lobachevsky. No. 1, pp. 270-273. 

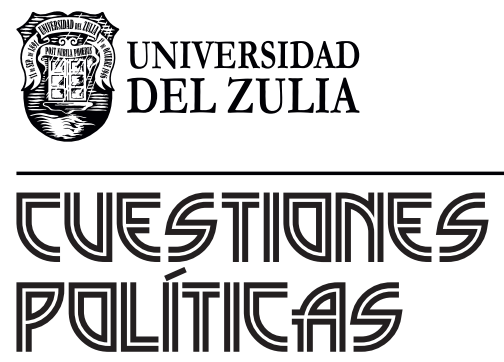

Vol. 39 N $^{\circ} 71$

Esta revista fue editada en formato digital y publicada en diciembre de 2021, por el Fondo Editorial Serbiluz, Universidad del Zulia. Maracaibo-Venezuela 